SITING TRANSLATION 



\title{
SITING TRANSLATION
}

\section{HISTORY, POST-STRUCTURALISM, AND THE COLONIAL CONTEXT}

\author{
Tejaswini Niranjana
}

University of California Press

Berkeley - Los Angeles - Oxford 
University of California Press

Berkeley and Los Angeles, California

University of California Press, Ltd.

Oxford, England

(C) 1992 by

The Regents of the University of California

Library of Congress Cataloging-in-Publication Data

Niranjana, Tejaswini, 1958-

Siting translation : history, post-structuralism, and the colonial context / Tejaswini Niranjana.

p. cm.

Includes bibliographical references (p. ) and index.

ISBN 0-520-07450-5 (cloth). - ISBN 0-520-07451-3 (paper)

1. Translating and interpreting. 2. Deconstruction.

3. Structuralism (Literary analysis). 4. Historicism.

5. Imperialism. I. Title.

PN241.N48 1992

$428^{\prime} .02911-\mathrm{dc} 20$

Printed in the United States of America

987654321

The paper used in this publication meets the minimum requirements of American National Standard for Information Sciences-Permanence of Paper for Printed Library Materials, ANSI Z39.48-1984. (6) 
To my parents,

Anupama Niranjana

and

K. S. Niranjana 
